\title{
Acute aortic dissection in pregnancy management with the fetus remaining in situ
}

\author{
DC Ferreira, IM Abreu, J Honório, PN Sampaio, F Binello, D Bastos, J Pierre, IH Carvalho, U Alves, A Bosiger, \\ PMS Pereira Filho, DH Silva, O Souza Neto* \\ From 23rd World Congress of the World Society of Cardio-Thoracic Surgeons \\ Split, Croatia. 12-15 September 2013
}

\section{Background}

Acute aortic dissection is one of the most dreaded clinical conditions during pregnancy. The limited experience reported in the literature does not allow the determination of guidelines for surgical management of aortic dissection in these cases. In this case presentation we successfully treated a 27-year-old woman with Marfan syndrome in the 36th week of pregnancy with acute type A aortic dissection, who underwent aortic repair with the fetus remaining in situ.

\section{Methods}

After a review of the data reported in the literature, we present this case of acute aortic dissection in a pregnancy woman with Marfan syndrome and discuss some new perspective of surgical management and maternal-fetal outcome considering the peculiarities of this disease's manifestation.

\section{Results}

Surgery for acute aortic dissection during pregnancy has been described by other investigators and, in most cases; the fetal outcome was relatively poor. The review of the data suggests that, in cases of fetal maturity, Cesarean section should be performed before or in combination with aortic repair. However, the appropriate surgical management with an immature fetus in utero remains unclear. The cardiopulmonary bypass (CPB) with the fetus in utero may itself represent a risk factor, as already demonstrated by studies that hypothermia contributes for a worse prognosis. We present a case of a 36th weeks pregnancy patient with Marfan syndrome who had acute type A Aortic dissection and underwent operative repair

\footnotetext{
* Correspondence: osouzaneto@globo.com

Department of Cardiovascular Surgery, Hospital Federal dos Servidores, Rio de Janeiro, Brazil
}

C 2013 Ferreira et al; licensee BioMed Central Ltd. This is an Open Access article distributed under the terms of the Creative Commons Attribution License (http://creativecommons.org/licenses/by/2.0), which permits unrestricted use, distribution, and reproduction in any medium, provided the original work is properly cited. with modified Bentall de Bono technique with the fetus remaining in situ, where during $\mathrm{CPB}$ was used high-flow, high pressure and mild hypothermia. The maternal-fetal outcome was excellent and an elective Cesarean of the fetus could be done one week later the aortic repair when the clinical conditions of the mother was completely stabilized and the fetus presented better maturity.

\section{Conclusions}

Despite the controversies of surgical management of aortic dissection during pregnancy because the lack of data, it seems to be possible as established in this case presentation, with the development of $\mathrm{CPB}$ and surgical techniques, perform the aortic repair with the fetus remaining in situ.

Published: 11 September 2013

doi:10.1186/1749-8090-8-S1-0255

Cite this article as: Ferreira et al:: Acute aortic dissection in pregnancy management with the fetus remaining in situ. Journal of Cardiothoracic Surgery 2013 8(Suppl 1):O255.

Submit your next manuscript to BioMed Central and take full advantage of:

- Convenient online submission

- Thorough peer review

- No space constraints or color figure charges

- Immediate publication on acceptance

- Inclusion in PubMed, CAS, Scopus and Google Scholar

- Research which is freely available for redistribution Submit your manuscript at
www.biomedcentral.com/submit Ciomed Central 